Plant Tissue Cult. \& Biotech. 26(1): 47-54, 2016 (June)

$\overline{\mathrm{PTC} \& \mathrm{~B}}$

\title{
Somatic Embryogenesis and Genetic Uniformity of Cassava Plants Regenerated from Secondary Somatic Cotyledons Preserved in Osmotic Agents
}

\author{
Jelili T. Opabode*, Olufemi V. Ajibola, Olufemi O. Oyelakin ${ }^{1}$ \\ and Oluyemisi A. Akinyemiju
}

Department of Crop Production and Protection, Obafemi Awolowo University, Ile-Ife, Nigeria

Key words: Cassava, Conservation, Somatic embryo, Slow growth

\begin{abstract}
Somatic embryogenesis, plant regeneration and genetic stability of regenerants grown from cassava secondary somatic cotyledon preserved at $16^{\circ} \mathrm{C}$ on medium containing mannitol or sorbitol alone and their combinations were investigated. Irrespective of osmotic agents in the medium, survival of cotyledon explant, frequency of somatic embryos, shoot induction, number of somatic embryo per explant, shoot elongation and rooting decreased as preservation period increased. The highest survival rate of cotyledon explants, frequency of somatic embryos, shoot induction and shoot elongation were observed on media containing $2 \%$ mannitol. However, the highest per cent rooting occurred on medium containing mannitol alone at 8 months after storage (MAS) and on media containing mannitol or sorbitol alone at 16 MAS. RAPD analysis suggested genetic uniformity among regenerants and their control plant. Osmotic preservation of secondary somatic embryos of cassava on $2 \%$ mannitol at $16^{\circ} \mathrm{C}$ is the best slow-growth method.
\end{abstract}

\section{Introduction}

An estimated 600 million people in tropical and subtropical climates depend on cassava (Manihot esculenta Crantz) as their source of energy (Bull et al. 2011). Despite its potentiality for achieving food security and economic growth, biotic and abiotic constraints such as diseases, pests, weeds, poor soil fertility and

*Author for correspondence: <jopabode@yahoo.com>. ${ }^{1}$ Center for Biotechnology, Federal University of Agriculture, Abeokuta, Nigeria. 
drought aremilitating against cassava production (Ceballos et al. 2004). Application of conventional breeding methods for cassava improvement has so far recorded limited successes (Ceballos et al. 2004). In the field, cassava is typically propagated clonally by stem cuttings. This propagation strategy is ideal for a transgenic approach to crop improvement, as gene segregation through outcrossing is limited.

To date, the only reported means genetic transformation of cassava plant is via regeneration through somatic embryogenesis. Currently, sub-culturing and re-cycling of somatic embryos for a lengthy period of time serve as constant sources of explants required for genetic transformation. However, re-cycling of cassava somatic embryos is cumbersome, reduces the frequency and efficiency of somatic embryogenesis and plant regeneration (Opabode et al. 2014). In addition, re-cycling somatic embryos induces genetic alteration as a result of the stress imposed on the plant tissues in culture which is incorporated in the form of DNA methylation, chromosome rearrangements and point mutations (Nadha et al. 2011). To overcome the aforementioned challenges, there is need to establish in vitro preservation procedure of cassava somatic embryo to serve as a reliable source of explants for genetic transformation.

Addition of mannitol and sorbitol to the culture media has been reported to be efficient in reducing growth and increasing the storage life of many in vitro grown tissues of different plant species (Shibli et al. 2006). Preservation of somatic embryos was first attempted by Withers (1979), who could only recover plantlets after secondary embryogenesis of freeze-preserved somatic embryos on semi-solid medium. Also, Jayansankar et al. (2005) successfully stored somatic embryos of grapevine for 26 months at $4^{\circ} \mathrm{C}$ with $80 \%$ plantlet recovery and genetic stability of regenerants. To our knowledge, storage of cassava somatic embryo on culture medium containing osmotic agents has not been reported.

The objectives of this study were to: (i) induce somatic embryogenesis from secondary somatic embryo cotyledons stored on media containing mannitol or sorbitol alone and their combinations at $16^{\circ} \mathrm{C}$, (ii) examine plant regeneration via shoot organogenesis using somatic cotyledon explants obtained in (i) and (iii) assess genetic uniformity of regenerated plants by RAPD markers.

\section{Materials and Methods}

The BM was used in all experiments unless otherwise stated. The BM consisted of full-strength MS salt (Sigma, USA) along with $0.8 \%$ (w/v) agar (Oxoid Ltd., England) and $30 \mathrm{~g} / \mathrm{l}$ sucrose. The $\mathrm{pH}$ of the medium was adjusted to $5.8 \mathrm{by} \mathrm{HCl}$ $(1 \mathrm{~N})$ or $\mathrm{NaOH}(1 \mathrm{~N})$ prior to autoclaving at $121^{\circ} \mathrm{C}$ for $15 \mathrm{~min}$ at $1.05 \mathrm{~kg} / \mathrm{cm}^{2}$ pressure. Growth regulators were filter-sterilized through $0.22 \mu \mathrm{M}$ millipore 
filters and added to media after autoclaving. For all experiments, except where otherwise stated, cultures were maintained in a $16 \mathrm{hrs}$ photoperiod with $20 \mu \mathrm{mol}$ $\mathrm{m}^{2} / \mathrm{s}$ light intensity provided by cool-white fluorescent tubes at $25 \pm 2^{\circ} \mathrm{C}$.

About 210 fresh cotyledonary-stage secondary somatic embryos were carefully removed from solid medium on which they were developed under sterile conditions. Isolated secondary embryos were transferred to fresh $\mathrm{BM}$ supplemented with $2 \%$ mannitol, $2 \%$ sorbitol, $4 \%$ mannitol, $4 \%$ sorbitol, $2 \%$ mannitol $+2 \%$ sorbitol, $2 \%$ mannitol $+4 \%$ sorbitol, $4 \%$ mannitol and $2 \%$ sorbitol and a control (free of osmotic agents) for 8 and 16 months in the dark at $16^{\circ} \mathrm{C}$. Preliminary studies have shown that storage at $16^{\circ} \mathrm{C}$ was the most suitable low temperature for a short-term preservation of cassava secondary somatic embryo (Opabode et al. 2015).

Cotyledons $(5 \mathrm{~mm})$ of secondary somatic embryos treated with the osmotic agents were cultured on BM supplemented with $6.0 \mathrm{mg} / \mathrm{l}$ of 2, 4-D under light. After three weeks of incubation, observation was made on the presence of embryogenic calli. Embryogenic calli were transferred to BM supplemented with $0.1 \mathrm{mg} / \mathrm{l}$ of BAP for maturation under light. Frequency of green somatic embryos and mean number of somatic embryo per explant after four weeks were recorded.

Cotyledons (5 mm) of green somatic embryos were cultured on BM supplemented with $1.0 \mathrm{mg} / \mathrm{l} \mathrm{BAP}$ and $0.5 \mathrm{mg} / \mathrm{l} \mathrm{IBA}$ (Sigma, USA). Per cent shootbud formation and number of shootbud per explant were recorded 14 days after incubation in the light. Thereafter, shootbuds were detached from the explants and transferred to BM supplemented with $1.0 \mathrm{mg} / \mathrm{l} \mathrm{BAP}$ and $10.0 \mathrm{IBA} \mathrm{mg} / \mathrm{l}$ for shoot elongation. Per cent shoot elongation was recorded two weeks after the transfer. Each elongated shoot was transferred to hormone-free basal medium for rooting as outlined by $\mathrm{Li}$ et al. (1998). Plantlets with well-developed roots were acclimatised and transferred to the greenhouse where they were grown to maturity.

The molecular technique of RAPD was used to determine the genetic stability of the regenerated plants as described by Opabode et al. (2015). A total of eight random decamer primers (Operon Tech, Alameda, USA) from B, C, D, and E series (OPB06, OPB08, OPB12, OPC01, OPC02, OPC05, OPC06, OPE19) were used for RAPD analysis. DNA fingerprints were visualized under UV light and photographed using a gel documenting system (Bio-Rad, CA, USA). RAPD analysis using each primer was repeated at least twice to establish the reproducibility of banding pattern of different DNA samples of cassava.

Treatments in each experiment were arranged in a completely randomized design with three replicates (10 explants each). Data were further subjected to 
analysis of variance to detect differences among treatments using the procedure of the Statistical Analysis Systems (SAS 2002). Means were separated by Tukey test at $5 \%$ level of probability.

\section{Results and Discussion}

Enlargement of cotyledon explants (Fig. 1A) occurred within two days of culture initiation and formed embryogenic callus (Fig. 1B) at the second week. The embryogenic callus produced green cotyledonary somatic embryo (Fig. 1C) under light incubation at the third week. Shootbuds (Fig.1D) emerged from the surface of cotyledon pieces cultured on shoot induction medium two weeks after incubation in the light. Thereafter, excised shootbuds were elongated and rooted (Fig. 1E) and established as young plants (Fig. 1F).
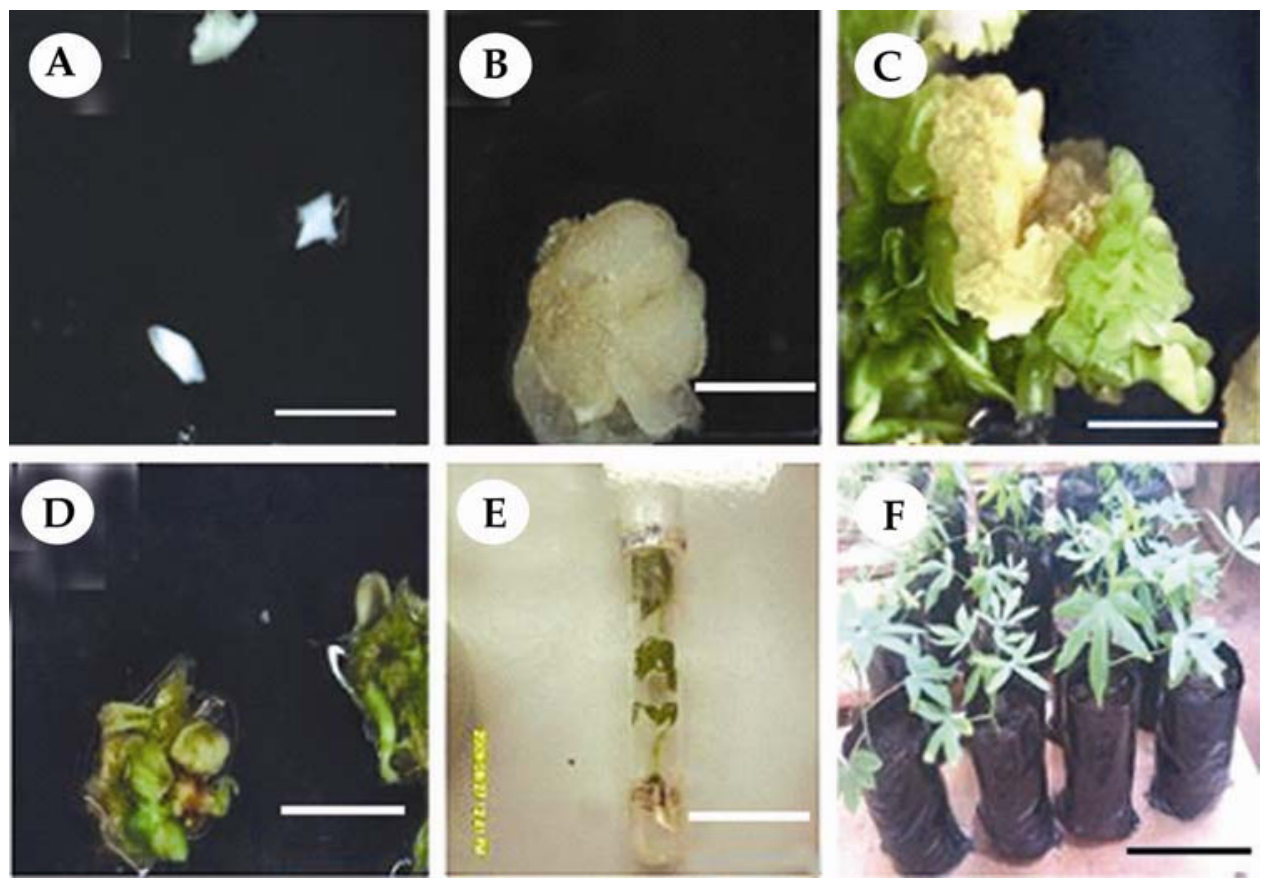

Fig. 1. Somatic embryogenesis and plant regeneration from secondary somatic embryos of cassava (variety TME) preserved at $16^{\circ} \mathrm{C}$ for 16 months. (A) An isolated secondary somatic embryo preserved on medium containing 2\% mannitol; (B) Fragments of embryos seen in A used for inducing somatic embryogenesis; (C) Embryogenic callus obtained from B two weeks after culture; (D) Green somatic embryos emerging from embryogenic callus; (E) Shoots inducted from fragment of D three weeks after culture; (F) Rooted plantlet obtained from E; (G) Acclimatized young plants from F. Bars represent $1.0 \mathrm{~cm}$.

The presence of mannitol or sorbitol alone and their combination in culture media had a significant $(p<0.05)$ effect on the survival of cotyledon explants, 
frequency of somatic embryo and shoot induction at both 8 and 16 MAS (Table 1). Survival of explants decreased as the period of preservation and concentration of mannitol or sorbitol alone or their combination increased. Shoot induction was not observed in all media free of osmotic agents (Table 1). The best survival rates of explants, frequency of somatic embryos and shoot induction were recorded on media supplemented with $2 \%$ mannitol at both 8 and 16 MAS. Our observation agrees with previous reports, which stated that higher concentrations of mannitol and sorbitol were toxic to plant tissue in vitro and that the phytoxicity of the osmotic agents in culture media is species-specific (Bekheet 2007, Lata et al. 2010).

Table 1. Effect of mannitol or sorbitol alone and their combination on survival of cotyledon explant, frequency of somatic embryo and shoot induction of secondary somatic embryos preserved for 8 and 16 months.

\begin{tabular}{|c|c|c|c|c|c|c|}
\hline \multirow{2}{*}{ Treatment } & \multicolumn{2}{|l|}{8 MAS } & \multicolumn{4}{|c|}{16 MAS } \\
\hline & Survival (\%) & FSE (\%) & SI (\%) & Survival (\%) & FSE (\%) & SI (\%) \\
\hline Mannitol 2\% & $80.5 \pm 3.2 \mathrm{a}$ & $56.4 \pm 2.8 \mathrm{a}$ & $92.3 \pm 4.3 a$ & $72.5 \pm 4.5 \mathrm{a}$ & $23.4 \pm 3.8 \mathrm{a}$ & $78.2 \pm 3.6 \mathrm{a}$ \\
\hline Mannitol 4\% & $77.3 \pm 5.2 a$ & $42.7 \pm 4.5 c$ & $70.1 \pm 4.5 b$ & $63.4 \pm 5.2 b$ & $18.5 \pm 2.7 \mathrm{~b}$ & $59.1 \pm 2.8 b$ \\
\hline Sorbitol $2 \%$ & $78.8 \pm 4.1 \mathrm{a}$ & $50.2 \pm 4.3 b$ & $76.7 \pm 4.0 \mathrm{~b}$ & $68.4 \pm 4.6 a$ & $18.2 \pm 2.2 b$ & $73.2 \pm 3.2 c$ \\
\hline Sorbitol $4 \%$ & $72.3 \pm 4.5 b$ & $38.9 \pm 3.4 c$ & $68.3 \pm 3.8 \mathrm{c}$ & $52.4 \pm 3.3 \mathrm{c}$ & $14.3 \pm 2.8 \mathrm{c}$ & $54.7 \pm 3.5 b$ \\
\hline $2 \% \mathrm{~S}+2 \% \mathrm{M}$ & $74.3 \pm 3.8 b$ & $28.6 \pm 3.7 d$ & $57.2 \pm 3.1 c$ & $20.1 \pm 3.1 d$ & $12.3 \pm 3.4 \mathrm{c}$ & $28.2 \pm 3.2 c$ \\
\hline $2 \% \mathrm{~S}+4 \% \mathrm{M}$ & $78.4 \pm 3.6 a$ & $27.2 \pm 3.2 d$ & $52.3 \pm 3.5 c$ & $15.3 \pm 2.9 \mathrm{~d}$ & $10.2 \pm 3.5 \mathrm{~d}$ & $20.3 \pm 4.6 \mathrm{~d}$ \\
\hline $4 \% S+2 \% M$ & $77.1 \pm 3.2 \mathrm{a}$ & $23.4 \pm 3.9 \mathrm{~d}$ & $43.5 \pm 2.8 \mathrm{~d}$ & $15.3 \pm 4.2 \mathrm{~d}$ & $10.2 \pm 2.3 d$ & $20.5 \pm 3.8 \mathrm{~d}$ \\
\hline Control & $43.8 \pm 4.2 \mathrm{c}$ & $12.5 \pm 3.7 \mathrm{e}$ & $0.0 \pm 0.0 \mathrm{e}$ & $12.5 \pm 2.7 \mathrm{~d}$ & $0.0 \pm 0.0 \mathrm{e}$ & $0.0 \pm 0.0 \mathrm{e}$ \\
\hline Mean & 77.4 & 50.2 & 65.8 & 64.5 & 30.9 & 59.7 \\
\hline
\end{tabular}

Values are means ( \pm standard error) of three replicates. Means followed by different letters in same column are significantly different at $5 \%$ level of probability according to Tukey Test. FSE = Frequency of somatic embryos, SI $=$ Shoot induction, NS $=$ Number of shootbud per explant, MAS = Month after storage, $\mathrm{S}=$ Sorbitol, $\mathrm{M}=$ Mannitol.

Number of shootbuds per explant, shoot elongation and rooting were significantly $(p<0.05)$ influenced by the presence of mannitol and sorbitol alone and in combination in culture media at both 8 and 16 MAS (Table 2). Number of shootbuds per explant decreased as the preservation period increased. The highest numbers of shootbuds per explant were recorded on media containing mannitol or sorbitol alone. As the period of preservation increased, the degree of shoot elongation became reduced. The highest frequency of shootbud elongated was observed on media containing $2 \%$ mannitol at both 8 and 16 MAS. The best rooting was observed on media containing mannitol at 8 MAS, while the media containing mannitol and sorbitol alone recorded the best rooting at 16 MAS. 
About $95 \%$ of plantlets from each treatment were acclimatized and grown to maturity under greenhouse conditions. Bekheet (2007) had previously reported the negative impacts of high concentrations of mannitol and sorbitol on shoot and root formation of globe artichoke.

Table 2. Effect of mannitol or sorbitol alone and their combinations on number of shootbud per explant, shoot elongation and rooting of somatic embryos preserved for 8 and 16 months.

\begin{tabular}{|c|c|c|c|c|c|c|}
\hline \multirow{2}{*}{ Treatment } & \multicolumn{3}{|c|}{8 MAS } & \multicolumn{3}{|c|}{16 MAS } \\
\hline & NS/explant & t SG (\%) & Rooting (\%) & NS/explant & SG (\%) & Rooting (\%) \\
\hline Mannitol 2\% & $3.4 \pm 0.6 a$ & $93.4 \pm 4.3 \mathrm{a}$ & $100.0 \pm 0.0 a$ & $2.8 \pm 0.5 a$ & $73.7 \pm 3.2 \mathrm{a}$ & $100.0 \pm 0.0 \mathrm{a}$ \\
\hline Mannitol $4 \%$ & $3.4 \pm 0.7 \mathrm{a}$ & $78.2 \pm 5.1 b$ & $100.0 \pm 0.0 \mathrm{a}$ & $2.8 \pm 0.8 \mathrm{a}$ & $50.2 \pm 2.8 b$ & $100.0 \pm 0.0 a$ \\
\hline Sorbitol $2 \%$ & $3.2 \pm 0.4 \mathrm{a}$ & $70.0 \pm 4.7 \mathrm{~b}$ & $82.4 \pm 6.9 c$ & $2.8 \pm 0.4 a$ & $35.3 \pm 2.5 c$ & $100.0 \pm 0.0 \mathrm{a}$ \\
\hline Sorbitol $4 \%$ & $3.3 \pm 0.6 a$ & $67.5 \pm 3.9 c$ & $73.7 \pm 4.3 \mathrm{~d}$ & $2.5 \pm 0.5 a$ & $37.5 \pm 2.1 \mathrm{c}$ & $100.0 \pm 0.0 \mathrm{a}$ \\
\hline $2 \% S+2 \% M$ & $2.4 \pm 0.4 b$ & $68.8 \pm 6.4 \mathrm{c}$ & $90.0 \pm 6.1 b$ & $1.2 \pm 0.2 b$ & $52.8 \pm 3.9 b$ & $62.7 \pm 4.3 b$ \\
\hline $2 \% \mathrm{~S}+4 \% \mathrm{M}$ & $2.2 \pm 0.5 b$ & $30.0 \pm 0.0 \mathrm{~d}$ & $93.6 \pm 7.2 b$ & $1.8 \pm 0.4 b$ & $27.8 \pm 4.8 \mathrm{~d}$ & $50.0 \pm 5.4 c$ \\
\hline $4 \% S+2 \% M$ & $2.0 \pm 0.3 b$ & $22.6 \pm 5.3 \mathrm{~d}$ & $82.4 \pm 6.7 c$ & $1.8 \pm 0.3 b$ & $30.3 \pm 4.2 \mathrm{~d}$ & $53.4 \pm 3.0 \mathrm{c}$ \\
\hline control & $0.0 \pm 0.0 c$ & $0.0 \pm 0.0 \mathrm{e}$ & $0.0 \pm 0.0 \mathrm{e}$ & $0.0 \pm 0.0 c$ & $0.0 \pm 0.0 \mathrm{e}$ & $0.0 \pm 0.0 \mathrm{~d}$ \\
\hline mean & 2.6 & 82.3 & 91.1 & 2.3 & 46.3 & 93.6 \\
\hline
\end{tabular}

Values are means ( \pm standard error) of three replicates. Means followed by different letters in same column are significantly different at $5 \%$ level of probability according to Tukey Test. SI = Shoot induction, NS = Number of shootbud per explant, SG = Shoot elongation, MAS = Month after storage, $\mathrm{S}=$ Sorbitol, $\mathrm{M}=$ Mannitol.

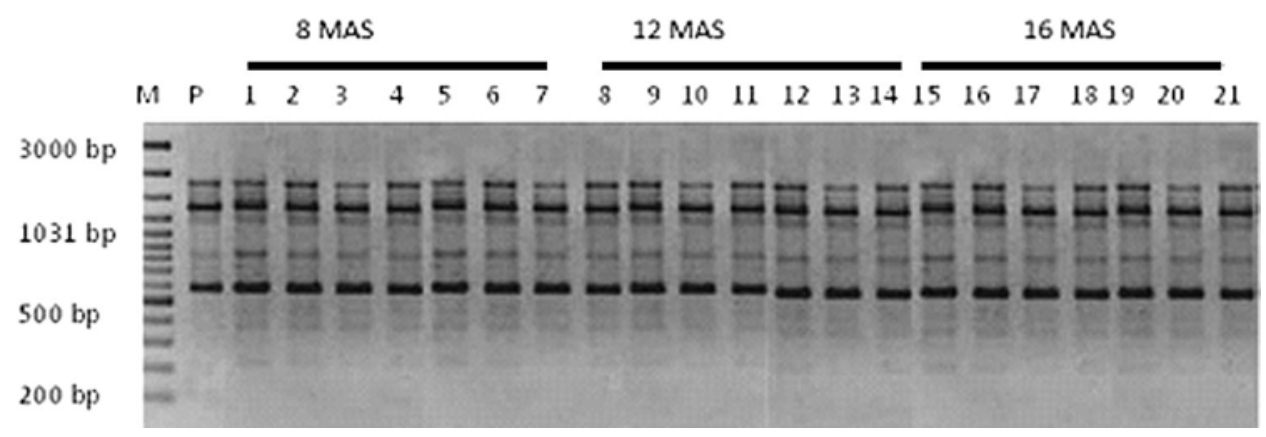

Fig. 2. Randomly amplified polymorphic DNA analysis for the primer OPC02. $\mathrm{M}=$ Gene Ruler ladder, $\mathrm{P}=$ Mother plant, 1-7 = Randomly selected samples from osmotic agents-treated plants after 8 months of storage, 8-14 - Randomly selected samples from osmotic agents-treated plants after 12 months of storage, 15-21 = Randomly selected samples from osmotic agents-treated plants after 16 months of storage. MAS = Month after storage.

RAPD analysis produced a total of 2408 bands from 43 plants using eight primers, each producing 56 distinct and scorable bands ranging from 250 to 3000 
bp in size. The bands were monomorphic (similar) among regenerated plants and the control plants (Fig. 2). Using a combination of RAPD and RFLP primers, Angel et al. (1996) demonstrated the genetic stability of cultured cassava germplasm at the DNA level after 10 years of in vitro storage by a slow growth method.

Present study has demonstrated that the regeneration ability of cassava secondary embryos could be retained for up to 16 months on media containing osmotic agents at low temperature. RAPD analysis suggested genetic uniformity among regenerants and their mother plants.

\section{Acknowledgement}

The authors appreciated the financial support of Obafemi Awolowo University Research Committee through grant No.11812AXP and National Agency for Biotechnology Development (NABDA), Abuja, Nigeria for the study.

\section{References}

Angel F, Barney VE, Tohme J and Roca WM (1996) Stability of cassava plants at the DNA level after retrieval from 10 years of in-vitro storage. Euphytica 90: 307-313

Bekheet SA (2007) In vitro preservation of globe artichoke Germplasm. Plant Tissue Cult. Biotech. 17: 1-9.

Bull SE, Ndunguru J, Gruissem W, Beeching JR and Vanderschuren H (2011) Cassava constraints to production and the transfer of biotechnology to African laboratories. Plant Cell Rep. 30: 677-679.

Ceballos H, Iglesias CA, Pereze JC and Dixon AGO (2004) Cassava breeding: Opportunities and challenges. Plant Mol. Biol. 56: 503-516.

Jayasankar SM, Aman V, Cordts J, Dhekney S, Li, ZT and Gray DJ (2005) Low temperature storage of suspension culture-derived grapevine somatic embryos and regeneration of plants. In Vitro Cell and Dev. Biol. Plant 41: 752-756.

Lata H, Moraes RM, Bertoni B and Pereira AMS (2010). In vitro germplasm conservation of Podophyllum peltatum L. under slow growth conditions. In Vitro Cell. Dev. Biol. Plant 46: 22-27.

Li HQ, Guo JY, Huang YW, Liang CY, Liu HX, Potrykus I and Puonti-Kaerlas J (1998) Regeneration of cassava plants via shoot organogenesis. Plant Cell Rep. 17: 410-414.

Nadha HK, Kumar R, Sharma RK, Anand M and Sood A (2011) Evaluation of clonal fidelity of in vitro raised plants of Guadua angustifolia Kunth using DNA-based markers. J. Med. Plant Res. 23: 5636-5641.

Opabode JT, Oyelakin OO, Akinyemiju OA and Ingelbrecht IL (2014) Influence of type and age of primary somatic embryo on secondary and cyclic somatic embryogenesis of cassava (Manihot esculenta Crantz). British Biotech. J. 4: 254-269. 
Opabode JT, Ajibola OV, Oyelakin OO and Akinyemiju OA (2015) Somatic embryogenesis and genetic uniformity of regenerated cassava plants from low-temperature preserved secondary somatic cotyledons. Biotech. 96: 246 -258

SAS Institute (2002): Statistical Analysis System "SAS/ STAT" User`s Guide, Version 6, Fourth edition; Vol. 1. The SAS Institute Inc., Gary, N.C.

Shibli RD, Shatnawi MA, Subaih WS and Ajlouni MM (2006) In vitro conservation and cryopreservation of plant genetic resources: A review. World J. Agril. Sci. 2: 372-382.

Withers LA (1979) Freeze preservation of somatic embryos and clonal plantlets of carrot (Daucus carota L.). Plant Physiol. 63: 460-467. 